\title{
11 \\ Storm Drainage System Modeling of Edmonton's Clareview and Pilot Sound Storm Basins
}

\author{
Steven Chan, Michelle Yu, Scott Neuman and \\ Magdy Hashem
}

The City of Edmonton operates and maintains over 5,000 km of sewer pipes. The collection system is made up of about $42 \%$ storm sewers, $39 \%$ sanitary sewers and $19 \%$ combined sewers. Storm drainage is captured and discharged to the North Saskatchewan River. Flows from the combined sewer area and the sanitary sewerage system are collected and discharged to the Gold Bar Wastewater Treatment Plant. This chapter presents the development and applications of the Clareview and Pilot Sound Storm Drainage Model. The study area is approximately 1350 ha and located on the north east side of the City servicing a population of about 18,000 mainly residential with portions of commercial, community services and industrial. A storm model was developed using DHI's Mike Urban and Mike Flood to represent approximately $69 \mathrm{~km}$ of 1,200 pipes and 370 sub-basins within the study boundary. Pipe diameters vary from $200 \mathrm{~mm}$ to $2250 \mathrm{~mm}$. The model also includes a pump station, five stormwater detention facilities and a number of flow diversion control structures. The main components of the study include development of model parameters and the drainage network, calibration and verification of the model, assessment of the capacity constraints of the existing system under various storm events, evaluation of the performance of the stormwater detention facilities under severe storm

Chan, S., M. Yu, S. Neuman and M. Hashem. 2009. "Storm Drainage System Modeling of Edmonton's Clareview and Pilot Sound Storm Basins." Journal of Water Management Modeling R235-11. doi: 10.14796/JWMM.R235-11.

(c) CHI 2009 www.chijournal.org ISSN: 2292-6062 (Formerly in Conceptual Modeling of Urban Water Systems. ISBN: 978-0-9808853-2-3) 
events, determination of system upgrade alternatives and the requirement for servicing the ultimate development stage and land use. The analysis also included a fully integrated and automated two-dimensional surface flooding model that connects the minor system (storm sewer network) with the major system (overland flow routes). Animation of the two-dimensional model simulation results were used to illustrate the extent of surface flooding within the study area.

\subsection{Introduction}

The Clareview and Pilot Sound basin is bounded by the Anthony Henday Transportation Utility Corridor (TUC) to the north, the North Saskatchewan River to the east, a topographic ridge east of 66 Street to the west and 137th Avenue to the south (see Figure 11.1). The study area is approximately 1,350 hectares; comprising mainly residential area in the southwest and east, industrial area in the north, and undeveloped area in the far north.

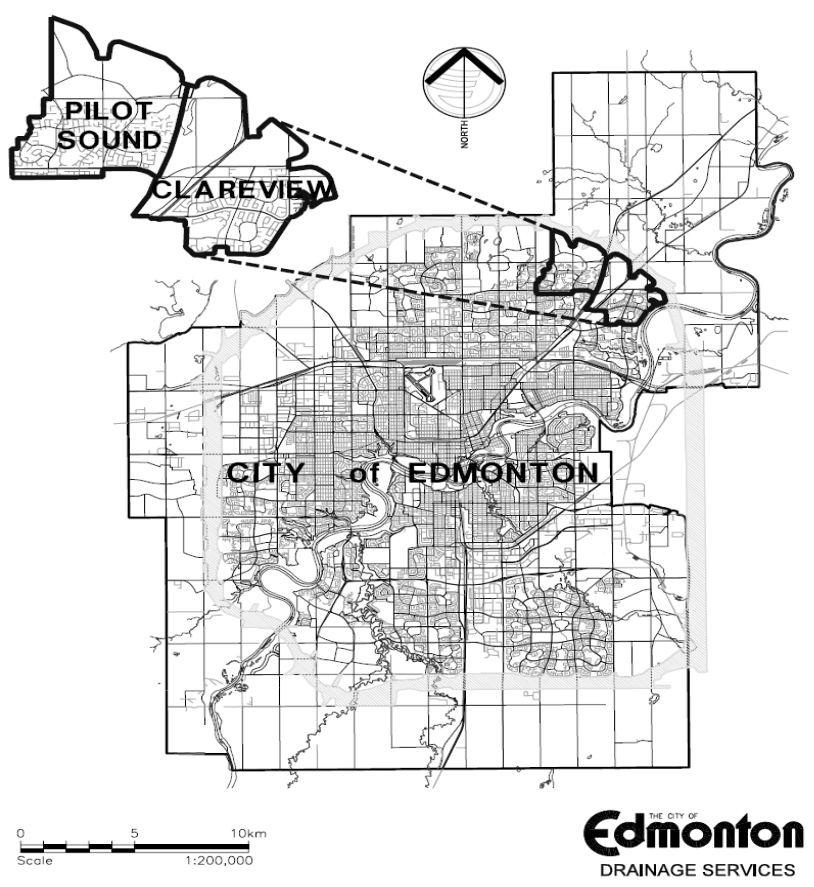

Figure 11.1 Study area. 
Historically, the study area has not suffered severe surface or basement flooding problems. With future development anticipated in the area, a hydraulic capacity assessment of the existing storm drainage system is required to determine existing and future peak flows, identify system constraints and determine upgrading alternatives such that future development can proceed without impacting the existing drainage system.

The overall objectives of this study are to:

- develop a hydro-dynamic model of the existing storm drainage network (piped system, detention lakes and surface routing);

- assess the capacity and constraints of the existing system under current land-use conditions;

- develop a hydrologic model of the future land-use condition and simulate the model to determine future peak flow estimates;

- evaluate the existing drainage system under future land-use conditions; and

- determine capital upgrades required to alleviate existing and future constraints such that future development can be sustained.

\subsection{Description of Study Area}

\subsubsection{Existing Land Use and Natural Drainage}

Recent aerial photography (September 2005) and current zoning information were collected and reviewed to identify the existing land use. The neighborhoods in Clareview are mainly residential with portions of commercial and community services. Residential areas have been developed in the past ten years in the southwest of Pilot Sound although some areas are still under development. The area between Clareview and Pilot Sound, the east sector and far north of Pilot Sound are undeveloped.

Natural drainage of the study area follows the topography of land generally in a northwest to southeast pattern towards the North Saskatchewan River. A major portion of nature runoff is intercepted by existing roads and railways. The intercepted flow is conveyed to existing 
storm services. A large part of the existing area northeast of Pilot Sound area is natural undeveloped area where the drainage paths are not well defined.

\subsubsection{Storm Drainage Network}

The City's storm sewers in the study area converge to one common outfall (\#75) through Clareview Storm Trunk as shown in Figure 11.2. The outfall discharges into the North Saskatchewan River near 144th Avenue and 20th Street. The existing Clareview Storm Trunk was constructed in 1980. The sewer trunk has been provided for drainage from the Clareview neighbourhoods and the Pilot Sound area. Pipe sizes in the Clareview Storm Trunk range from $1650 \mathrm{~mm}$ to $2250 \mathrm{~mm}$ in diameter. In Pilot Sound Area, upstream of the trunk sewers, there is a series of local sewer networks that discharge to stormwater lakes - where peak runoff rates are detained and discharged into the trunk sewers at a controlled rate.

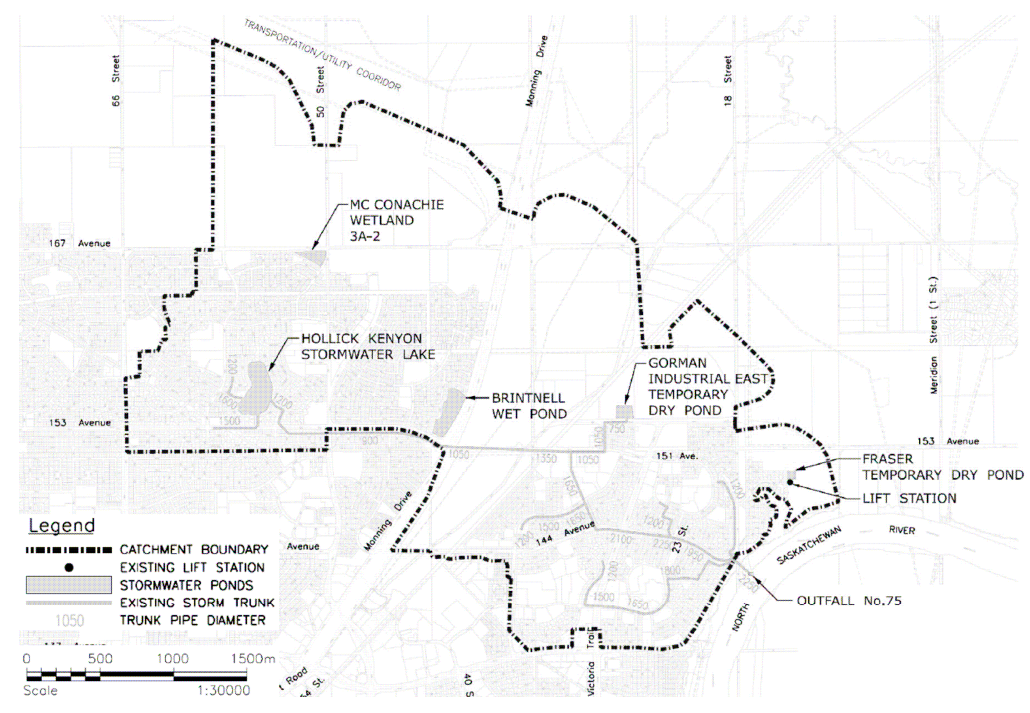

Figure 11.2 Storm drainage network.

There are approximately $69 \mathrm{~km}$ pipes and corresponding manholes, five existing stormwater management facilities (SWMF), and an existing lift station in the study area. 


\subsubsection{Rain Gauge}

There is an existing rain gauge within the study area, Rain Gauge 37 at Fraser. Two other existing rain gauges, Rain Gauge 32 and Rain Gauge 38, are at west and southwest of the study area, respectively, as shown in Figure 11.3.

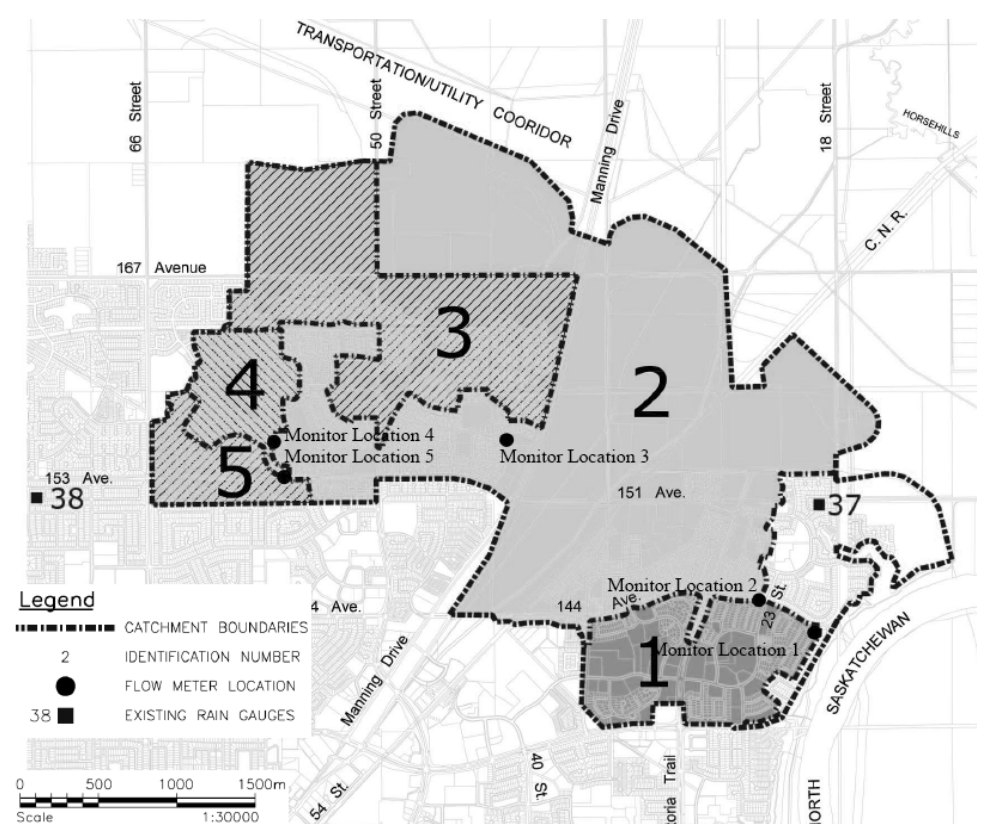

Figure 11.3 Rain gauge and flow meter locations.

\subsection{Model Development}

DHI's MIKE URBAN version 2007 is used to model the stormwater sewer system. MIKE URBAN is a GIS based modeling system for modeling and design of water distribution networks and collection systems of wastewater and stormwater (DHI Water \& Environment, 2005). MIKE URBAN Collection Systems (CS) is the successor to MOUSE, and is designed for stormwater and wastewater analyses. CS-Pipeflow and CS-Rainfall-Runoff 
modules are the two core modules in MIKE URBAN CS, which were used in the Clareview and Pilot Sound stormwater system modeling.

A two-dimensional (2D) surface flooding model was incorporated into the MIKE URBAN model. With this innovative approach, MIKE URBAN was used to model and simulate the pipe system and DHI's MIKE 21 was used to model surface flooding and overland flow. In this study, MIKE FLOOD was used to dynamically couple the one-dimensional (1D) sewer system model, MIKE URBAN, with 2D surface water model, MIKE 21 (see Figure 11.4). MIKE FLOOD allows modeling of floodplains in 2D, while at the same time also models the one dimensional sewer hydraulic system (DHI Water \& Environment, 2007).

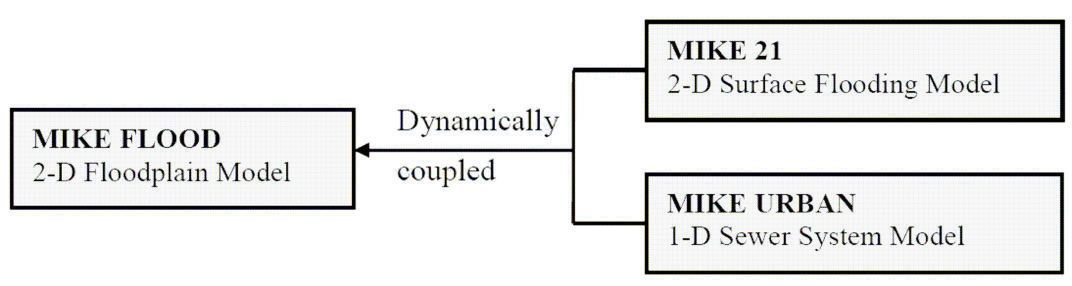

Figure 11.4 Mike flood model structure.

\subsubsection{Hydraulic Model Development}

After the physical properties of the storm sewer system were obtained, a review of the integrity of the data was completed which included a review of the storm sewers, manholes, SWMFs, and ditches and their associated attributes (i.e. diameter, invert elevations, material type, etc.). A review of hydraulic connectivity was also completed to determine potential data gaps (i.e. missing pipes or missing manholes). As-built drawings and approved engineering record drawings were reviewed. They were used to fill the data gaps, delineate sub-catchment boundaries, and obtain the SWMF configurations. The dimensions of the control structures was also obtained from as-builts and confirmed on field.

The storm sewer model developed in this study includes all of the trunk sewers and local collectors located within the study area. It consists of approximately 1160 pipes and the corresponding nodes, five SWMFs, four weirs, four orifices, and one lift station. 


\subsubsection{Hydrologic Model Development}

Field reconnaissance of the study area was conducted to review drainage areas, imperviousness, and surface soil conditions of the watershed. The minor and major system flow routes were also investigated and the current land use was confirmed during the field reconnaissance.

The study area is approximately 1350 ha. The sub-catchments were delineated on a catch basin set by catch basin set basis where possible, which resulted in the creation of 368 sub-catchment areas. The sizes of the sub-catchments range from 0.2 ha, which is a mature residential area located at Hollick Kenyan, to $72 \mathrm{ha}$, which is undeveloped area located northwest of the study area. The length of each catchment was calculated based on topo contours and the lengths used in the model range from $22 \mathrm{~m}$ to $3300 \mathrm{~m}$. The slopes of several sub-catchments were investigated in order to determine the average slope of the each sub-catchment. The investigation revealed that the average slopes for most sub-catchment are approximately 1 to $2 \%$. Therefore, sub-catchment slopes were initially entered as 1 to $2 \%$ for all subcatchments (Earth Tech, 2007a).

The imperviousness ratio values were assigned to each sub-catchment based on the existing land-use. The imperviousness ratio values used for each type of land-use in the model are substantially consistent with the imperviousness suggested by the City Standard (Table 11.1). Model drain (inflow) nodes were assigned to each sub-catchment area to be able to simulate the runoff entering the hydraulic network based on the existing topographical and drainage patterns. Surface runoff Model "B" - Kinematic Wave (Non-linear reservoir) was used as runoff model.

Table 11.1 Storm runoff coefficients and imperviousness according to city's zoning.

\begin{tabular}{ccc}
\hline $\begin{array}{c}\text { Zone or Classification Designation } \\
\text { Per Bylaw \# 5910 }\end{array}$ & $\begin{array}{c}\text { Runoff } \\
\text { Coefficient }\end{array}$ & $\begin{array}{c}\text { Imperviousness } \\
(\%)\end{array}$ \\
\hline Agriculture \& Undeveloped Area & 0.2 & $10-50$ \\
Public Park Open & 0.3 & $10-50$ \\
Residential & 0.5 & $40-65$ \\
Institutional & 0.3 & $10-50$ \\
Urban Reserve & 0.5 & $40-65$ \\
Commercial & 0.9 & $40-100$ \\
\hline
\end{tabular}


MIKE URBAN hydrological computations assume a constant spatial rainfall distribution for each storm event where in reality this is not the case. Rains are characterized by variable rates of rainfall over space. In this study, the study area was divided into two parts and two sets of the rainfall data recorded from two rain gauges were input in the Mike Urban hydrological model to represent the rainfall boundary conditions for the two areas. The rainfall data recorded at Rain Gauge 37 was used as the rainfall boundary condition for the Clareview area, which is close to Rain Gauge 37; while the rainfall data recorded at Rain Gauge 38 was used as the rainfall boundary condition for the Pilot Sound area, which is close to Rain Gauge 38. This exercise reduced the impact of the non-uniform rainfall spatial distribution on the overall peak flow and volume. The rainfall spatial variability over the study area was discussed in section 11.4.2.

\subsection{Model Calibration}

\subsubsection{Flow Monitoring Program}

It is essential that the hydraulic model closely matches the "real system". To achieve this goal five flow meters were installed through the local and trunk sewer system (both upstream and downstream of the stormwater lakes). They were installed prior to the rainfall season during the summer of 2007 to record flows within the storm sewers. The flow monitoring data in turn was used to calibrate the hydrologic and hydraulic modules. Figure 11.3 illustrates the locations of the flow meters, including the catchment areas contributing to each flow meter (Earth Tech, 2007b).

\subsubsection{Selection of Calibration Event}

The rainfall and flow monitoring data was collected from May 1 to August 6, 2007. During the rainfall and flow monitoring period, there were no significant rainfall events. The three largest events were in the order of a one in 2 y return period. These events occurred on May 3-6, July 17-18 and July 24. Table 11.2 summarizes the rainfall measured at the three rain gauges near the study area. As shown in Table 11.2 the spatial distribution of these rainfall events varied significantly.

The rainfall of July 24 event was distributed more uniformly than the other events. This July 24 event peaked at a 1 to $3 \mathrm{~h}$ duration, whereas the other events peaked at $10 \mathrm{~min}$ or $24 \mathrm{~h}$. The 1 to $3 \mathrm{~h}$ duration is more 
reasonable for the time of concentration for this study area. Therefore, the July 24 event was selected as the calibration event, and the other two events were used as validation events.

Table 11.2 Rainfall data of three events in 2007 summer.

\begin{tabular}{c|cccccc}
\hline & \multicolumn{2}{|c}{ May 3-6 Event } & \multicolumn{2}{c}{ July 17-18 Event } & \multicolumn{2}{c}{ Jul-24 Event } \\
Rain & $\begin{array}{c}\text { 24 Hour } \\
\text { Rainfall } \\
\text { Depth (mm) }\end{array}$ & $\begin{array}{c}\text { Max. 5 Minute } \\
\text { Intensity } \\
(\mathrm{mm} / \mathrm{hr})\end{array}$ & $\begin{array}{c}\text { 24 Hour } \\
\text { Rainfall } \\
\text { Depth (mm) }\end{array}$ & $\begin{array}{c}\text { Max. 5 Minute } \\
\text { Intensity } \\
(\mathrm{mm} / \mathrm{hr})\end{array}$ & $\begin{array}{c}\text { 24 Hour } \\
\text { Rainfall } \\
\text { Depth (mm) }\end{array}$ & $\begin{array}{c}\text { Max. } \\
\text { 5 Minute } \\
\text { Intensity } \\
(\mathrm{mm} / \mathrm{hr})\end{array}$ \\
\hline 32 & 32.9 & 9.6 & 3.6 & 2.4 & 15.7 & 27.6 \\
37 & 16.4 & 8.4 & 12.1 & 40.8 & 14.4 & 38.4 \\
38 & 33.8 & 8.4 & 4.6 & 4.8 & 25.5 & 62.4 \\
\hline
\end{tabular}

\subsubsection{Calibration Results}

The model calibration results indicate that the modeled flow and volumes are close to the measured flow and volumes at the flow monitoring locations for the July 24 event, as shown in Table 11.3. The simulated peak flow also matches reasonably well the observed peak flow in terms of the time series at five monitoring locations although some discrepancies were found (See Figure 11.5 to Figure 11.9).

Table 11.3 Model calibration results for July 24, 2007 event.

\begin{tabular}{cccccc}
\hline & Location & Location & Location & Location & Location \\
& 1 & 2 & 3 & 4 & 5 \\
\hline Volume Measured (cu.m) & 2756 & 30439 & 7036 & 3454 & 2787 \\
Volume Modeled (cu.m) & 4249 & 30125 & 7642 & 4500 & 4448 \\
Volume difference (\%) & 54.2 & -1 & 8.6 & 30.3 & 59.6 \\
Peak Measured Flow (cu.m/s) & 0.88 & 1.24 & $1.02 *$ & $1.88 *$ & 1.04 \\
Peak Modeled Flow (cu.m/s) & 0.85 & 1.14 & 0.79 & 1.15 & 1.01 \\
Peak Flow difference (\%) & -3.9 & -8.2 & -23.1 & -36.3 & -3.3 \\
\hline
\end{tabular}

Note: * bad data identified by checking the quality of the monitoring data. 


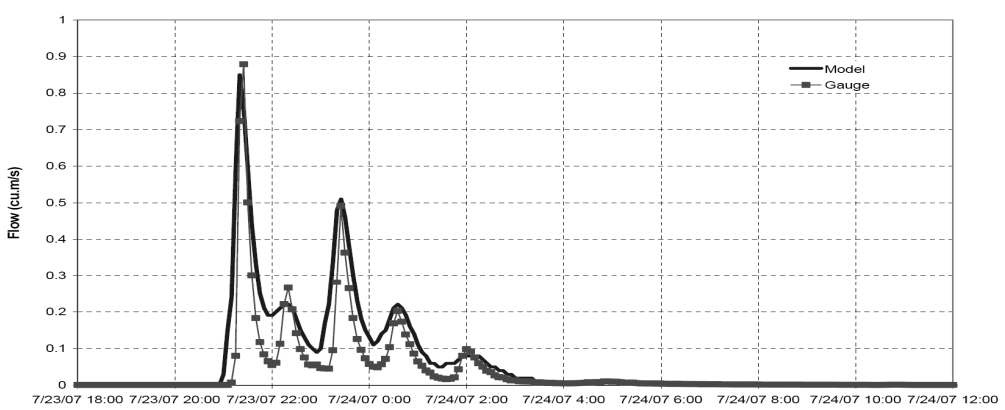

Figure 11.5 Calibration results at monitoring location one.

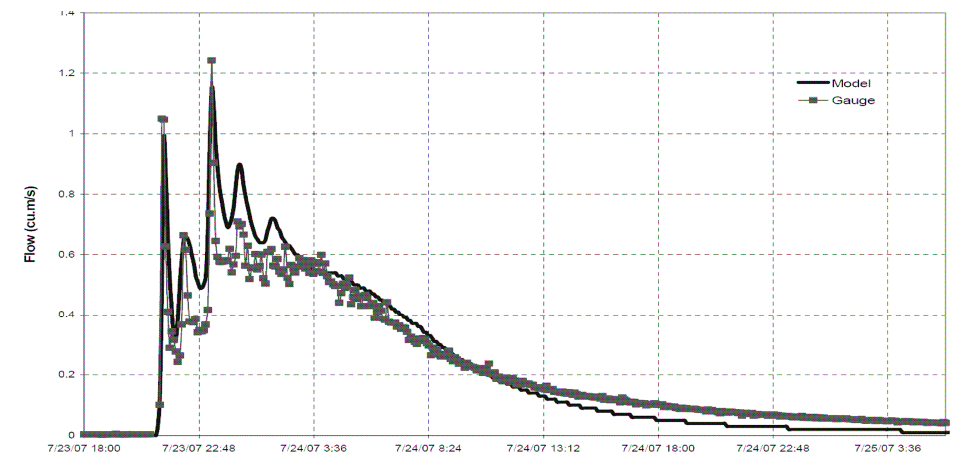

Figure 11.6 Calibration results at monitoring location two.

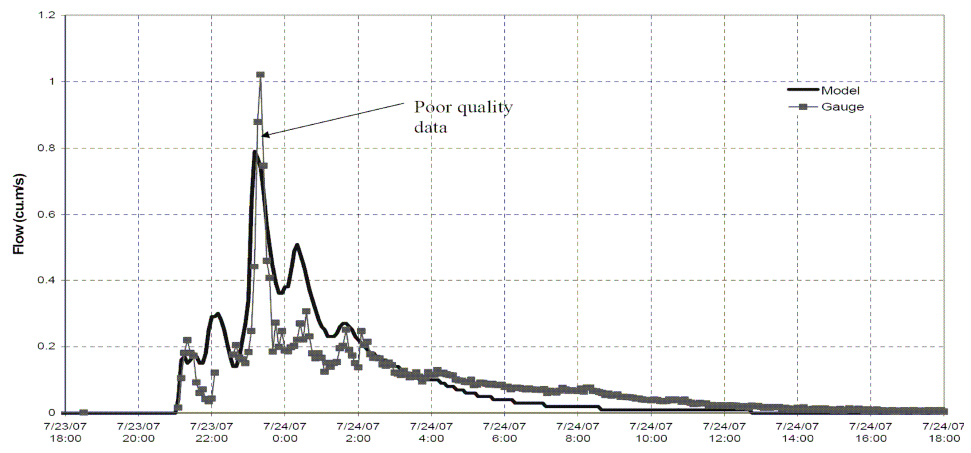

Figure 11.7 Calibration results at monitoring location three. 


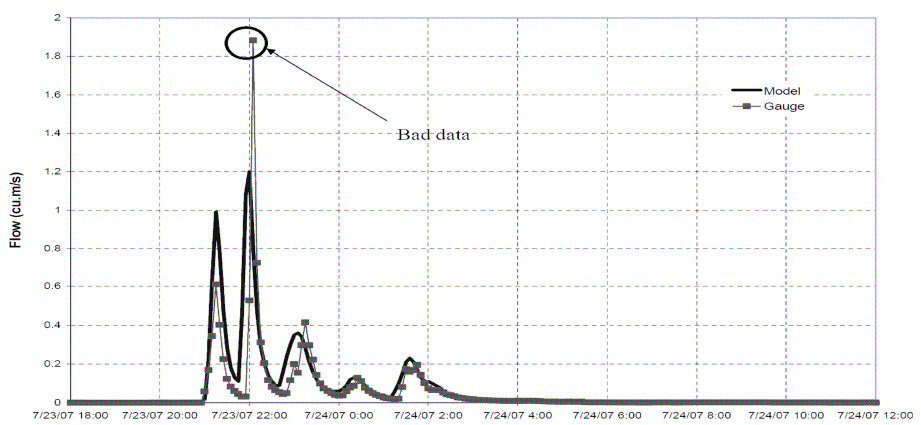

Figure 11.8 Calibration results at monitoring location four.

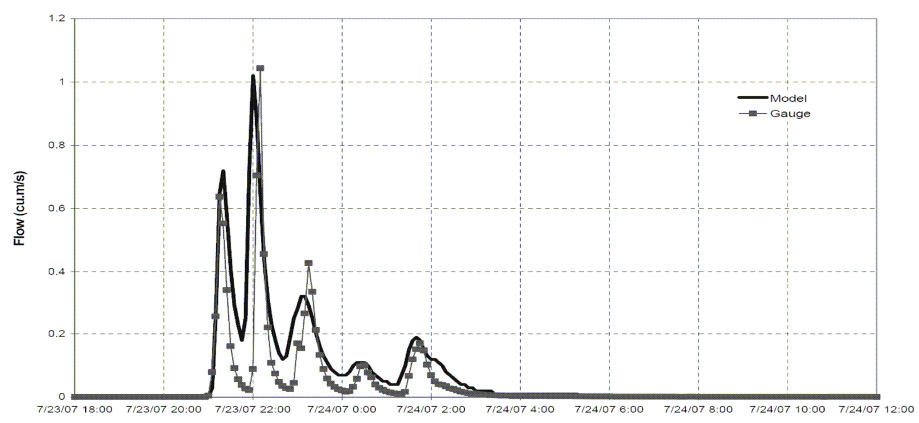

Figure 11.9 Calibration results at monitoring location five.

After the model was calibrated, two additional recorded rainfall events were simulated to further verify the model results. A good correlation and comparison was achieved for the verification events as shown in Table 11.4 and Table 11.5.

Table 11.4 Model verification results for May 3, 2007 event.

\begin{tabular}{cccccc}
\hline & Location & Location & Location & Location & Location \\
& 1 & 2 & 3 & 4 & 5 \\
\hline Volume Measured (cu.m) & 12537 & 143057 & 39505 & 17334 & 12699 \\
Volume Modeled (cu.m) & 8443 & 90195 & 29980 & 9177 & 9973 \\
Volume difference (\%) & -32.7 & -37.0 & -24.1 & -42.5 & -19.7 \\
Peak Measured Flow (cu.m/s) & 0.39 & 1.20 & 0.67 & 0.35 & 0.29 \\
Peak Modeled Flow (cu.m/s) & 0.39 & 1.11 & 0.64 & 0.36 & 0.34 \\
Peak Flow difference (\%) & 1.0 & -7.4 & -4.2 & 2.2 & 18.5 \\
\hline
\end{tabular}


Table 11.5 Model verification results for July 17, 2007 event.

\begin{tabular}{cccccc}
\hline & Location & Location & Location & Location & Location \\
& 1 & 2 & 3 & 4 & 5 \\
\hline Volume Measured (cu.m) & 3683 & 5403 & 1348 & 811 & 670 \\
Volume Modeled (cu.m) & 4661 & 7065 & 1495 & 285 & 286 \\
Volume difference (\%) & 26.6 & 30.8 & 11.0 & -64.9 & -57.3 \\
Peak Measured Flow (cu.m/s) & 1.80 & 1.70 & 0.22 & 0.18 & 0.14 \\
Peak Modeled Flow (cu.m/s) & 1.86 & 1.78 & 0.22 & 0.05 & 0.05 \\
Peak Flow difference (\%) & 3.6 & 4.3 & -2.0 & -72.3 & -66.6 \\
\hline
\end{tabular}

The factors contributed to the variability in model results versus the observed data include the spatial distribution of rainfall across the study area, the influence of snow melt, and the quality of measured data.

The variable spatial distribution of the rainfall during the actual event is a key source of discrepancies. MIKE URBAN hydrological computations assume a constant spatial rainfall distribution where in reality rains are characterized by variable intensities and patterns over space within the study area. The recorded rainfall data shown in Table 11.2 shows the variable spatial distribution of the rainfall. This inconsistency, therefore, gives rise to the discrepancy of the simulation. In this study, the study area was divided into two parts and two sets of the rainfall data recorded from two rain gauges were input in the hydrological model to represent the rainfall for the two areas. This approach reduced the impact of the rainfall spatial distribution on overall peak flow and volume.

Another source of discrepancies is the influence of snow melt. It was observed that most landscaping areas and stormwater lakes were covered by thick snow and ice during our March 2007 field reconnaissance. According to Environment Canada's climate data, the mean temperature of April 2007 was $2.7^{\circ} \mathrm{C}$ at Edmonton International Airport. The total snow depth was $21.0 \mathrm{~cm}$ in April 2007 and $10.9 \mathrm{~cm}$ in May 2007 (Environment Canada, 2007). Based on the climate information and model verification results, it is believed that the ground was covered with snow during the May 3-6 rainfall event. Therefore rainfall during the early period of the May 3-6 event likely caused snow to melt, thus increasing flows and the runoff hydrograph in the storm sewers. Because this snow melt occurred over a prolonged period, the snow runoff did not significantly increase peak flows but it had a large affect on runoff volumes. As a result, the volumes were underestimated by $19.7 \%$ to $42.5 \%$. 


\subsection{Storm Sewer System Review}

A hydraulic capacity assessment of the storm sewer system was conducted with the aid of the developed MIKE URBAN Model. The objective of the assessment was to evaluate the capacity of the storm sewer system and to identify system "deficiencies" (limited hydraulic capacity, surcharging, road flooding, etc.). The storm sewer system performance under existing conditions was modeled for the 5 y $4 \mathrm{~h}, 25$ y $4 \mathrm{~h}, 100$ y $4 \mathrm{~h}$ and 100 y $24 \mathrm{~h}$ design storms as defined in the City of Edmonton Design Standards (The City of Edmonton, 2004). The storm sewer system was also modeled for the 1978 and 1991 historical storms.

\subsubsection{Existing Development Scenario}

The existing storm sewers were evaluated by reviewing the ratio of peak flow over pipe full-flow capacity $\left(\mathrm{Q}_{\text {peak }} / \mathrm{Q}_{\text {full }}\right)$. Table 11.6 provides a general summary of the number, diameter range and length of existing storm sewers under different capacity utilization ratios under the design storm events.

Table 11.6 Summary of storm sewer capacity utilization (existing).

\begin{tabular}{c|cccc}
\hline \multirow{2}{*}{$\mathrm{Q}_{\text {peak }} / \mathrm{Q}_{\text {full }}$ Ratio } & \multicolumn{4}{|c}{$\%$ of Total Length } \\
& $5 \mathrm{y}-4 \mathrm{~h}$ & $25 \mathrm{y}-4 \mathrm{~h}$ & $100 \mathrm{y}-4 \mathrm{~h}$ & $100 \mathrm{y}-24 \mathrm{~h}$ \\
\hline $0-1.0$ & 88 & 66 & 63 & 93 \\
$1.0-1.2$ & 5 & 12 & 13 & 2 \\
$1.2-1.5$ & 4 & 12 & 12 & 2 \\
Greater Than 1.5 & 3 & 10 & 12 & 3 \\
Total & 100 & 100 & 100 & 100 \\
\hline
\end{tabular}

In addition to assessing the pipe capacities, the system was reviewed with respect to HGLs and surface flooding in the system. Table 11.7 provides a summary of the peak HGLs and surface flooding for all manholes under different design storm events.

The model simulation results show that during a $5 \mathrm{y}$ return period event, $12 \%$ of sewers in the study area exceed the desired Q peak/Q full ratio of 1.0 and $2 \%$ of the manholes are expected to surcharge to the road surface under existing development conditions. Thirty-four percent (34\%) of sewers exceed the design capacities and $22 \%$ of the manholes are expected to surcharge to the road surface during a $25 \mathrm{y}$ return period event. Thirty-seven percent $(37 \%)$ of sewers exceed their design capacities and $32 \%$ of the 
manholes are expected to surcharge to the road surface during a $100 \mathrm{y}$ return period event.

Table 11.7 Summary of HGLs at manholes (existing).

\begin{tabular}{c|cccc}
\hline \multirow{2}{*}{ Depth Below Ground } & \multicolumn{4}{|c}{$\%$ of Manholes } \\
& $5 \mathrm{y}-4 \mathrm{~h}$ & $25 \mathrm{y}-4 \mathrm{~h}$ & $100 \mathrm{y}-4 \mathrm{~h}$ & $100 \mathrm{y}-24 \mathrm{~h}$ \\
\hline Above Ground (surface flooding) & 2 & 22 & 32 & 1 \\
$0-1.0 \mathrm{~m}$ Below Ground & 5 & 12 & 10 & 2 \\
$1.0-2.0 \mathrm{~m}$ Below Ground & 12 & 12 & 11 & 6 \\
$>2.0 \mathrm{~m}$ Below Ground & 81 & 54 & 47 & 91 \\
Total & 100 & 100 & 100 & 100 \\
\hline
\end{tabular}

Areas south of Clareview and west of Pilot Sound are anticipated to experience street flooding during a $25 \mathrm{y} 4 \mathrm{~h}$ event. Most of the neighbourhoods within the study area would experience street flooding or surcharge to ground during a $100 \mathrm{y} 4 \mathrm{~h}$ event. The street ponding during a $25 \mathrm{y}$ return period event or less frequent events increases the possibility of in infiltration and inflow in the sanitary sewer system that could cause basement backups.

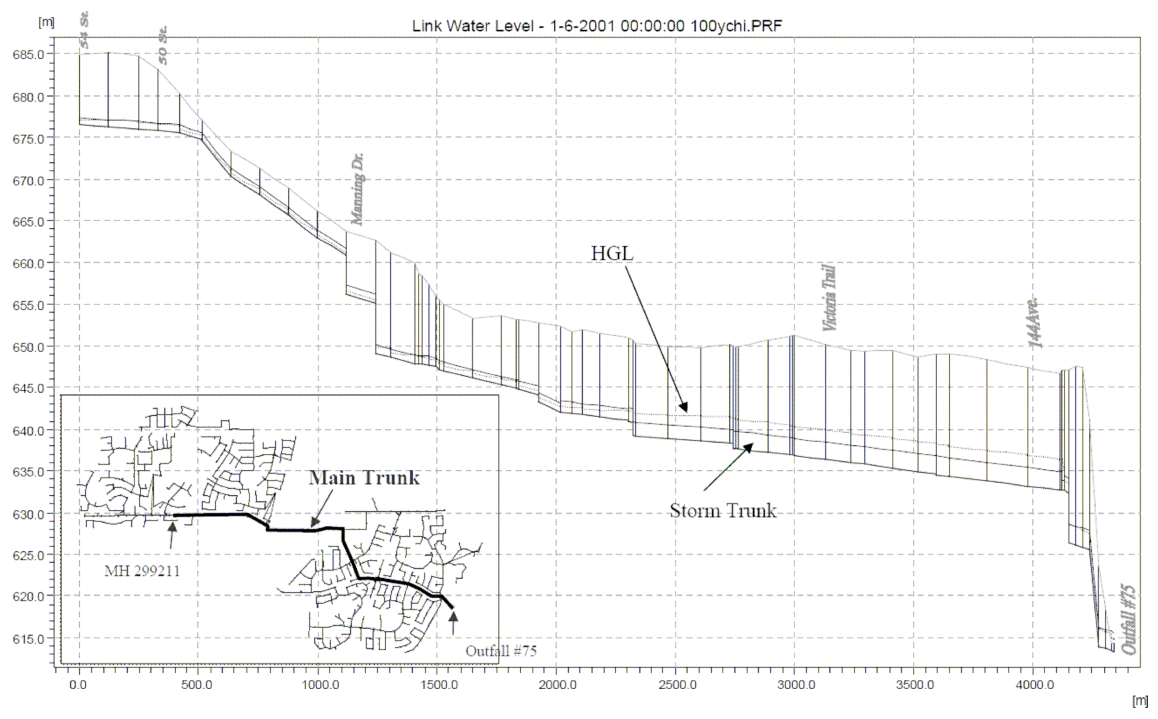

Figure 11.10 HGL profile of main storm trunk. 
Figure 11.10 shows that the HGL in the existing main storm trunk during a 100 y $4 \mathrm{~h}$ storm event. Significant surcharging is not anticipated in the main storm trunks and the majority of the main storm trunk functions adequately during the $100 \mathrm{y}$ event. In the study area, the lakes collect and detain runoff from over $50 \%$ of tshe entire study area; as a result the lakes have a significant impact on reducing peak flows in the trunk sewers. The model results show that the stormwater detention ponds reduce the peak flow in the trunk sewers. For instance, the peak inflow into Hollick Kenyon Lake is attenuated from $11.5 \mathrm{cu} . \mathrm{m} / \mathrm{s}$ to $0.44 \mathrm{cu} . \mathrm{m} / \mathrm{s}$ during a $100 \mathrm{y} 4 \mathrm{~h}$ event. The peak inflow to Brintnell Lake is $12.7 \mathrm{cu} . \mathrm{m} / \mathrm{s}$ and the discharge from the lake is $0.73 \mathrm{cu} . \mathrm{m} / \mathrm{s}$. Table 11.8 shows the effectiveness of these stormwater detention ponds on peak flow attenuation.

Table 11.8 Effectiveness of detention ponds (100 y $4 \mathrm{~h}$ event).

\begin{tabular}{cccc}
\hline Stormwater Detention Pond & $\begin{array}{c}\text { Inflow } \\
(\mathrm{cu.m} / \mathrm{s})\end{array}$ & $\begin{array}{c}\text { Outflow } \\
(\mathrm{cu.m} / \mathrm{s})\end{array}$ & $\begin{array}{c}\text { \% of Peak } \\
\text { Flow Shedding }\end{array}$ \\
\hline Hollick Kenyon Wet Pond & 11.5 & 0.44 & 96.2 \\
Brintnell Wet Pond & 12.7 & 0.73 & 94.3 \\
McConachie 3A-2 Wetland & 3.1 & 0.42 & 86.5 \\
$\begin{array}{c}\text { Gorman Industrial East } \\
\text { Temporary Pond }\end{array}$ & 0.4 & 0.05 & 87.5 \\
Fraser Temporary Pond & 2.1 & 0.04 & 98.1 \\
\hline
\end{tabular}

\subsubsection{Ultimate Development Scenario}

Based on the Area Master Plan (Reid Crowther, 1991), the current undeveloped areas are proposed to be mainly residential with portions of industrial and commercial under ultimate scenario. The projected population for Clareview and Pilot Sound is 43,000 by 2013.

The hydraulic capacity of the storm sewer system was also assessed for the ultimate development scenario. Similar to the existing system assessment, the objective of the assessment was to evaluate the capacity of the storm sewer system under ultimate development scenario, and then identify system "deficiencies".

Table 11.9 shows the summary of the system capacity utilization under ultimate development scenario during design storm events. Table 11.10 provides a summary of the peak HGLs and surface flooding at manholes for these events. 
Table 11.9 Summary of storm sewer capacity utilization (ultimate).

\begin{tabular}{c|cccc}
\hline \multirow{2}{*}{$\mathrm{Q}_{\text {peak }} / \mathrm{Q}_{\text {full }}$ Ratio } & \multicolumn{4}{|c}{$\%$ of Total Length } \\
& $5 \mathrm{y}-4 \mathrm{~h}$ & $25 \mathrm{y}-4 \mathrm{~h}$ & $100 \mathrm{y}-4 \mathrm{~h}$ & $100 \mathrm{y}-24 \mathrm{~h}$ \\
\hline $0-1.0$ & 87 & 66 & 65 & 97 \\
$1.0-1.2$ & 6 & 12 & 13 & 1 \\
$1.2-1.5$ & 4 & 12 & 11 & 0.5 \\
Greater than 1.5 & 3 & 10 & 12 & 1.5 \\
Total & 100 & 100 & 100 & 100 \\
\hline
\end{tabular}

Table 11.10 Summary of HGL's at manholes (ultimate).

\begin{tabular}{c|cccc}
\hline \multirow{2}{*}{ Depth Below Ground } & \multicolumn{4}{|c}{$\%$ of Manholes } \\
& $5 \mathrm{y}-4 \mathrm{~h}$ & $25 \mathrm{y}-4 \mathrm{~h}$ & $100 \mathrm{y}-4 \mathrm{~h}$ & $100 \mathrm{y}-24 \mathrm{~h}$ \\
\hline $\begin{array}{c}\text { Above Ground } \\
\text { (surface flooding) }\end{array}$ & 3 & 19 & 33 & 0.5 \\
$0-1.0 \mathrm{~m}$ Below Ground & 5 & 13 & 12 & 1 \\
$1.0-2.0 \mathrm{~m}$ Below Ground & 11 & 23 & 13 & 5.5 \\
$>2.0$ m Below Ground & 81 & 45 & 42 & 93 \\
Total & 100 & 100 & 100 & 100 \\
\hline
\end{tabular}

Thirteen percent $(13 \%)$ of sewers are predicted to exceed the desired $\mathrm{Q}_{\text {peak }} / \mathrm{Q}_{\text {full }}$ ratio of 1.0 and 3\% of the manholes are expected to surcharge to the road surface during a $5 \mathrm{y}$ return period event. Thirty four percent $(34 \%)$ of sewers are predicted to exceed the design capacities and $19 \%$ of the manholes are expected to surcharge to the road surface during a $25 \mathrm{y}$ return period event. Thirty five percent (35\%) of sewers are predicted to exceed their design capacities and $33 \%$ of the manholes are expected to surcharge to the road surface during a $100 \mathrm{y}$ return period event.

The majority of the existing main sewer trunk from 153rd Avenue and 54th Street to Outfall \#75 has adequate capacity to handle a $25 \mathrm{y}$ event because the runoff from approximately $70 \%$ of the study area would be regulated by the existing and future stormwater detention ponds.

\subsection{Storm Management Facility Review}

The existing stormwater management facilities were also evaluated. The performance of the existing stormwater management facilities under existing 
conditions was modeled for 5 y 4 h, 25 y 4 h, 100 y 4 h, and 100 y $24 \mathrm{~h}$ design storms.

The modeling results show that the existing stormwater management ponds can accommodate the runoff from 100 y $24 \mathrm{~h}$ storm under existing land-use conditions (Earth Tech, 2008).

The three existing permanent SWMFs were also evaluated under the ultimate development conditions. The evaluation results show that the existing stormwater management ponds still can accommodate the runoff from 100 y $24 \mathrm{~h}$ storm under ultimate land-use conditions. The two temporary SWMFs will be replaced by future permanent SWMFs under ultimate development scenario.

\subsection{Surface Flooding Model Development}

In this project, MIKE 21 is used to simulate the overland flow at urban areas when the storm sewer systems surcharge to the ground.

The topographic map of the study area was imported into the bathymetry editor to produce the digital elevation model for MIKE 21 model. In this MIKE 21 model, the grid size was defined as $5 \mathrm{~m} \times 5 \mathrm{~m}$ in order to obtain reasonable model run times and manageable sized model output files. The MIKE 21 model was established to cover the entire study area. The model contains 840,000 grids in total.

After MIKE URBAN model and MIKE 21 model were developed, MIKE FLOOD integrated them into a single, dynamically coupled modeling system. MIKE FLOOD links a node/manhole in MIKE URBAN with one or more cells/elements in MIKE 21. The urban link in MIKE FLOOD describes the interaction of water when a manhole is over topped or when overland flow enters a storm water network.

Overland flow during 25 y $4 \mathrm{~h}, 100$ y $4 \mathrm{~h}$, and 100 y $24 \mathrm{~h}$ design storms were simulated using MIKE FLOOD model to evaluate the extend of surface flooding.

\subsection{Proposed Upgrade Plan}

\subsubsection{Recommended Improvements}

The City of Edmonton Design Standards require that the storm drainage system should meet the required level-of-service objectives. The objectives 
are to avoid all property damage and flooding and to minimize inconvenience to the public due to runoff from $5 \mathrm{y}$ and more frequent rainfall events and to avoid significant property damage from a $100 \mathrm{y}$ return frequency rainfall event. To meet the level-of-service objectives, the design criteria used to determine necessary upgrades in this study include: to eliminate all surface flooding during a $5 \mathrm{y}$ rainfall event, to minimize street ponding, consequently reducing the possibility of runoff infiltration/ inflow into sanitary system during infrequent rainfall events, and to accommodate the runoff from a 100 y $24 \mathrm{~h}$ design event in stormwater management facilities.

The model simulation shows that most of the existing storm sewer system in the study area functions adequately under existing and ultimate development conditions. Therefore, major upgrading is not immediately required. The proposed improvements are essentially to optimize the storm drainage system performance.

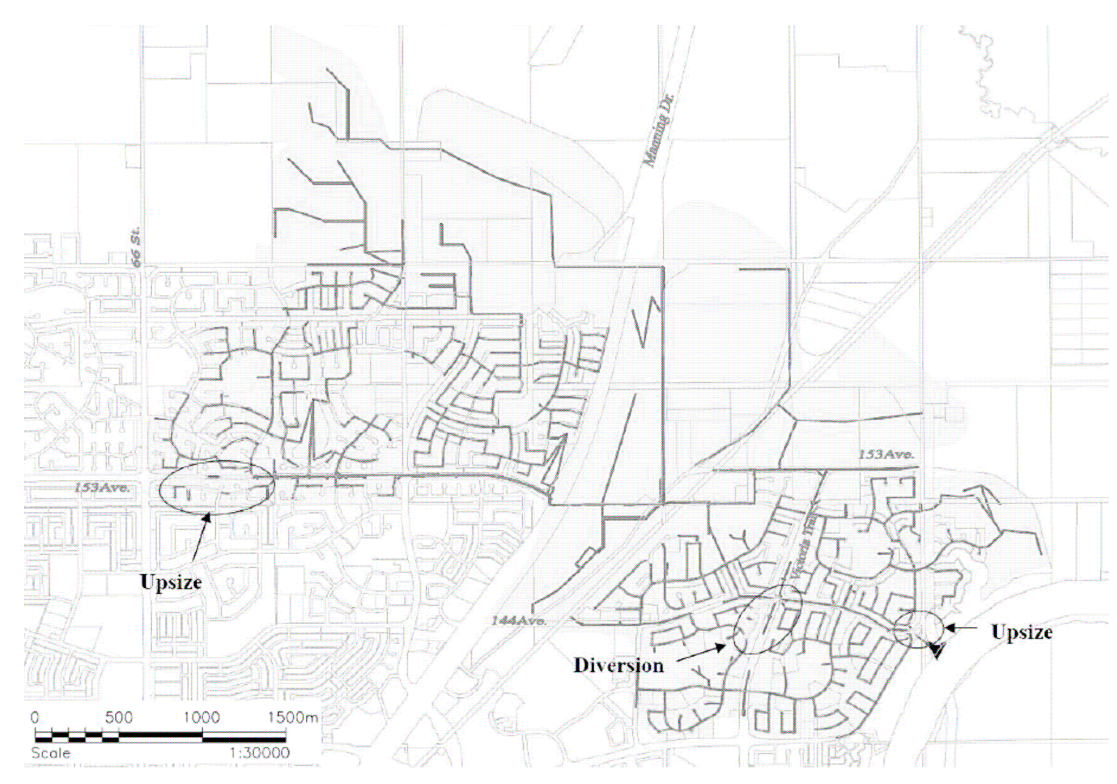

Figure 11.11 Proposed upgrading plan.

Since the capacity utilization levels of the main trunks are relatively low compared to the local storm sewers, the strategy of the improvements is to divert some flow to the trunks. The other recommended improvements are to 
upsize some undersized pipes. The recommended upgrades were obtained thorough trial and error. The upgrades include:

- upsize $675 \mathrm{~m}$ of sewers at the west side of the study area;

- install $120 \mathrm{~m}$ and upsize $247 \mathrm{~m}$ of sewers to divert flow to the main trunk at the south side of the Clareview; and

- upsize $20 \mathrm{~m}$ of undersized main trunk near the storm outfall to $2250 \mathrm{~mm}$ diameter.

The recommended improvements are shown in Figure 11.11.

\subsubsection{Project Benefits}

\section{Under Existing Scenario}

The simulation results show that with the proposed improvement, all flooded manholes would be eliminated during a $5 \mathrm{y}$ storm event. The proposed upgrades would also reduce the surcharging levels of the storm sewers in the western area of the Pilot Sound during $25 \mathrm{y} 4 \mathrm{~h}$ and 100 y $24 \mathrm{~h}$ events. The proposed upgrades may not reduce the street flooding during $100 \mathrm{y} 4 \mathrm{~h}$ events, however, they would reduce the street ponding duration. The street ponding duration is expected to be reduced from $1.5 \mathrm{~h}$ to 45 min during a $25 \mathrm{y} 4 \mathrm{~h}$ event, and the street ponding duration is predicted to be reduced from $3.3 \mathrm{~h}$ to $1.8 \mathrm{~h}$ during a $100 \mathrm{y} 4 \mathrm{~h}$ event.

The benefits of the proposed upgrades are summarized in Table 11.11 to Table 11.13.

Table 11.11 Summary of surface flooding improvements (existing scenario).

\begin{tabular}{|c|c|c|c|c|c|c|c|c|}
\hline \multirow{2}{*}{ Depth Below Ground } & \multicolumn{4}{|c|}{$\begin{array}{l}\% \text { of Manholes } \\
\text { (Before Upgrading) }\end{array}$} & \multicolumn{4}{|c|}{$\begin{array}{l}\% \text { of Manholes } \\
\text { (After Upgrading) }\end{array}$} \\
\hline & $\begin{array}{l}5 \mathrm{y} \\
4 \mathrm{~h}\end{array}$ & $\begin{array}{c}25 \mathrm{y} \\
4 \mathrm{~h}\end{array}$ & $\begin{array}{l}100 \mathrm{y} \\
4 \mathrm{~h}\end{array}$ & $\begin{array}{l}100 \mathrm{y} \\
24 \mathrm{~h}\end{array}$ & $\begin{array}{l}5 \mathrm{y} \\
4 \mathrm{~h}\end{array}$ & $\begin{array}{c}25 \mathrm{y} \\
4 \mathrm{~h}\end{array}$ & $\begin{array}{l}100 \mathrm{y} \\
4 \mathrm{~h}\end{array}$ & $\begin{array}{l}100 \mathrm{y} \\
24 \mathrm{~h}\end{array}$ \\
\hline Above Ground & 2 & 22 & 32 & 1 & 0 & 19 & 33 & 1 \\
\hline $\begin{array}{c}0-1.0 \mathrm{~m} \text { Below } \\
\text { Ground } \\
1.0-2.0 \mathrm{~m} \text { Below }\end{array}$ & 5 & 12 & 10 & 2 & 1 & 13 & 14 & 1 \\
\hline Ground & 12 & 12 & 11 & 6 & 9 & 12 & 12 & 5 \\
\hline$>2.0 \mathrm{~m}$ Below Ground & 81 & 54 & 47 & 91 & 90 & 55 & 41 & 92 \\
\hline Total & 100 & 100 & 100 & 100 & 100 & 100 & 100 & 100 \\
\hline
\end{tabular}


Table 11.12 Capacity utilization improvements (existing scenario).

\begin{tabular}{|c|c|c|c|c|c|c|c|c|}
\hline \multirow{2}{*}{$\mathrm{Q}_{\text {peak }} / \mathrm{Q}_{\text {full }}$ Ratio } & \multicolumn{4}{|c|}{$\begin{array}{l}\% \text { of Total Length } \\
\text { (Before Upgrading) }\end{array}$} & \multicolumn{4}{|c|}{$\begin{array}{l}\% \text { of Total Length } \\
\text { (After Upgrading) }\end{array}$} \\
\hline & $\begin{array}{l}5 \mathrm{y}- \\
4 \mathrm{y}\end{array}$ & $\begin{array}{l}25 \mathrm{y}- \\
4 \mathrm{~h}\end{array}$ & $\begin{array}{l}100 \mathrm{y}- \\
4 \mathrm{~h}\end{array}$ & $\begin{array}{l}100 \mathrm{y}- \\
24 \mathrm{~h}\end{array}$ & $\begin{array}{l}5 \mathrm{y}- \\
4 \mathrm{~h}\end{array}$ & $\begin{array}{l}25 \mathrm{y}- \\
4 \mathrm{~h}\end{array}$ & $\begin{array}{c}100 \mathrm{y}- \\
4 \mathrm{~h}\end{array}$ & $\begin{array}{l}100 \mathrm{y}- \\
24 \mathrm{~h}\end{array}$ \\
\hline $0-1.0$ & 88 & 66 & 63 & 93 & 89 & 67 & 60 & 95 \\
\hline $\begin{array}{l}1.0-1.2 \\
1.2-1.5\end{array}$ & $\begin{array}{l}5 \\
4\end{array}$ & $\begin{array}{l}12 \\
12\end{array}$ & $\begin{array}{l}13 \\
12\end{array}$ & $\begin{array}{l}2 \\
2\end{array}$ & $\begin{array}{l}4 \\
4\end{array}$ & $\begin{array}{l}12 \\
10\end{array}$ & $\begin{array}{l}14 \\
13\end{array}$ & $\begin{array}{l}1 \\
1\end{array}$ \\
\hline $\begin{array}{c}\text { Greater Than } 1.5 \\
\text { Total }\end{array}$ & $\begin{array}{c}3 \\
100\end{array}$ & $\begin{array}{c}10 \\
100\end{array}$ & $\begin{array}{c}12 \\
100\end{array}$ & $\begin{array}{c}3 \\
100\end{array}$ & $\begin{array}{c}3 \\
100\end{array}$ & $\begin{array}{c}11 \\
100\end{array}$ & $\begin{array}{c}13 \\
100\end{array}$ & $\begin{array}{c}3 \\
100\end{array}$ \\
\hline
\end{tabular}

Table 11.13 Surface flooding duration (existing scenario).

\begin{tabular}{cccc}
\hline $\begin{array}{c}\text { Return } \\
\text { Frequency }\end{array}$ & Existing (h) & $\begin{array}{c}\text { After Proposed } \\
\text { Upgrades }(\mathrm{h})\end{array}$ & $\begin{array}{c}\text { Reduction in } \\
\text { Duration }(\mathrm{h})\end{array}$ \\
\hline 1 in 5 year & 0.3 & 0 & 0.3 \\
1 in 25 year & 1.5 & 0.8 & 0.7 \\
1 in 100 year & 3.3 & 1.8 & 1.5 \\
\hline
\end{tabular}

\section{Under Ultimate Scenario}

Table 11.14 to Table 11.16 show the benefits of the proposed upgrades under ultimate development conditions. The proposed improvements is predicted to eliminate all flooding manholes during a $5 \mathrm{y}$ storm event, and reduce the surcharging levels of the storm sewers at 153rd Avenue and $152 \mathrm{C}$ Avenue at west of the Pilot Sound during $25 \mathrm{y}$ and $100 \mathrm{y}$ events. The proposed upgrades would also reduce the street ponding duration.

Table 11.14 Surface flooding improvements (ultimate scenario).

\begin{tabular}{c|cccc|cccc}
\hline & \multicolumn{3}{|c|}{ \% of Manholes } & \multicolumn{4}{c}{ \% of Manholes } \\
(After Upgrading) \\
\cline { 2 - 8 } Depth Below Ground & $5 \mathrm{y}$ & $25 \mathrm{y}$ & $100 \mathrm{y}$ & $100 \mathrm{y}$ & $5 \mathrm{y}$ & $25 \mathrm{y}$ & $100 \mathrm{y}$ & $100 \mathrm{y}$ \\
& $4 \mathrm{~h}$ & $4 \mathrm{~h}$ & $4 \mathrm{~h}$ & $24 \mathrm{~h}$ & $4 \mathrm{~h}$ & $4 \mathrm{~h}$ & $4 \mathrm{~h}$ & $24 \mathrm{~h}$ \\
\hline Above Ground & 3 & 19 & 33 & 1 & 0 & 18 & 31 & 0 \\
$0-1.0 \mathrm{~m}$ Below Ground & 5 & 13 & 12 & 1 & 0 & 14 & 13 & 1 \\
$1.0-2.0 \mathrm{~m}$ Below Ground & 11 & 23 & 13 & 5 & 9 & 14 & 9 & 5 \\
$>2.0 \mathrm{~m}$ Below Ground & 81 & 45 & 42 & 93 & 91 & 54 & 47 & 94 \\
Total & 100 & 100 & 100 & 100 & 100 & 100 & 100 & 100 \\
\hline
\end{tabular}


Table 11.15 Capacity utilization improvements (ultimate scenario).

\begin{tabular}{|c|c|c|c|c|c|c|c|c|}
\hline \multirow{2}{*}{$\mathrm{Q}_{\text {peak }} / \mathrm{Q}_{\text {full }}$ Ratio } & \multicolumn{4}{|c|}{$\begin{array}{l}\% \text { of Total Length } \\
\text { (Before Upgrading) }\end{array}$} & \multicolumn{4}{|c|}{$\begin{array}{l}\% \text { of Total Length } \\
\text { (After Upgrading) }\end{array}$} \\
\hline & $\begin{array}{l}5 \mathrm{y} \\
4 \mathrm{~h}\end{array}$ & $\begin{array}{l}25 \mathrm{y} \\
4 \mathrm{~h}\end{array}$ & $\begin{array}{c}100 \mathrm{y} \\
4 \mathrm{~h}\end{array}$ & $\begin{array}{l}100 \mathrm{y} \\
24 \mathrm{~h}\end{array}$ & $\begin{array}{l}5 \mathrm{y} \\
4 \mathrm{~h}\end{array}$ & $\begin{array}{c}25 \mathrm{y} \\
4 \mathrm{~h}\end{array}$ & $\begin{array}{c}100 \mathrm{y} \\
4 \mathrm{~h}\end{array}$ & $\begin{array}{l}100 \mathrm{y} \\
24 \mathrm{~h}\end{array}$ \\
\hline $0-1.0$ & 87 & 66 & 65 & 97 & 90 & 68 & 65 & 97.5 \\
\hline $1.0-1.2$ & 6 & 12 & 13 & 1 & 5 & 11 & 13 & 1 \\
\hline $1.2-1.5$ & 4 & 12 & 11 & 0.5 & 3 & 11 & 11 & 0.5 \\
\hline Greater than 1.5 & 3 & 10 & 12 & 1.5 & 2 & 10 & 11 & 1 \\
\hline Total & 100 & 100 & 100 & 100 & 100 & 100 & 100 & 100 \\
\hline
\end{tabular}

Table 11.16 Surface flooding duration (ultimate scenario).

\begin{tabular}{cccc}
\hline $\begin{array}{c}\text { Return } \\
\text { Frequency }\end{array}$ & $\begin{array}{c}\text { Before Proposed } \\
\text { Upgrades (h) }\end{array}$ & $\begin{array}{c}\text { After Proposed } \\
\text { Upgrades }(\mathrm{h})\end{array}$ & $\begin{array}{c}\text { Reduction in } \\
\text { Duration }(\mathrm{h})\end{array}$ \\
\hline 1 in 5 year & 0.5 & 0 & 0.5 \\
1 in 25 year & 1.7 & 1.0 & 0.7 \\
1 in 100 year & 2.7 & 1.7 & 1.0 \\
\hline
\end{tabular}

\subsection{Conclusions}

This chapter presents a methodology to develop a fully integrated 2-dimensional computer model for an urban storm drainage system using DHI's Mike Urban and Mike Flood software. The hydraulic model was developed and calibrated using recent flow and rainfall measurements. Using the calibrated model, the capacity of the existing drainage system was evaluated and the effectiveness of the detention facilities was assessed. Drainage constraints and locations of flooding were identified. The needs for capital improvements were also identified. The hydraulic model was an effective tool which aided in highlighting sewers with excess capacity as well as the potential for using detention facilities to attenuate peak flows and reduce trunk sewer sizing. The study results are expected to provide the City of Edmonton with a tool, which can continue to be used as an effective tool to assist with strategic planning of future development and capital works, as well as the potential for optimizing the existing infrastructure through managing assets, timely planning of sewer expansions and rehabilitations. 


\section{References}

DHI Water \& Environment (2005). MIKE URBAN Model Manager User Guide, pp. 17.

DHI Water \& Environment (2007). MIKE Flood User Manual, pp. 11.

Earth Tech Canada. (2007b). Clareview and Pilot Sound Drainage Study, Technical

Memorandum \#1 - Background Data Review and Collection, prepared for the City of Edmonton, April 2007, pp. 6.

Earth Tech Canada. (2007a). Clareview and Pilot Sound Drainage Study, Technical Memorandum \#2 - Model Development, prepared for the City of Edmonton, October 2007, pp. 10.

Earth Tech Canada. (2008). Clareview and Pilot Sound Drainage Study, Technical Memorandum \#3 - Existing System Analysis, prepared for the City of Edmonton, January 2008 , pp. 9.

Environmrnt Canada, (2007), Climate Data Online, http://www.climate.weatheroffice.ec.gc.ca/climateData/canada_e.html

Reid Crowther \& Partner Ltd. (1991). The City of Edmonton Pilot Sound Area Master Plan, prepared for the City of Edmonton, November 1991, pp. 6-8.

The City of Edmonton (2004). Design and Construction Standards, Volume 3 Drainage, pp. 37-38 